\title{
Eye Morphology and Retinal Topography in Hummingbirds (Trochilidae: Aves)
}

\author{
Thomas J. Lisney ${ }^{a}$ Douglas R. Wylie ${ }^{a, b}$ Jeffrey Kolominsky ${ }^{b}$ \\ Andrew N. Iwaniukc \\ ${ }^{a}$ Department of Psychology, and b ${ }^{\mathrm{b}}$ Neurosciences and Mental Health Institute, University of Alberta, \\ Edmonton, Alta., and ' Department of Neuroscience, Canadian Centre for Behavioural Neuroscience, \\ University of Lethbridge, Lethbridge, Alta., Canada
}

\section{Key Words}

Bird · Fovea · Retinal ganglion cell · Stereology · Vision ·

Visual ecology

\begin{abstract}
Hummingbirds are a group of small, highly specialized birds that display a range of adaptations to their nectarivorous lifestyle. Vision plays a key role in hummingbird feeding and hovering behaviours, yet very little is known about the visual systems of these birds. In this study, we measured eye morphology in 5 hummingbird species. For 2 of these species, we used stereology and retinal whole mounts to study the topographic distribution of neurons in the ganglion cell layer. Eye morphology (expressed as the ratio of corneal diameter to eye transverse diameter) was similar among all 5 species and was within the range previously documented for diurnal birds. Retinal topography was similar in Amazilia tzacatl and Calypte anna. Both species had 2 specialized retinal regions of high neuron density: a central region located slightly dorso-nasal to the superior pole of the pecten, where densities reached $\sim 45,000$ cells $\cdot \mathrm{mm}^{-2}$, and a temporal area with lower densities $\left(38,000-39,000\right.$ cells $\left.\cdot \mathrm{mm}^{-2}\right)$. A weak visual streak bridged the two high-density areas. A retina from Phaethornis superciliosus also had a central high-
\end{abstract}

density area with a similar peak neuron density. Estimates of spatial resolving power for all 3 species were similar, at approximately $5-6$ cycles $\cdot$ degree $^{-1}$. Retinal cross sections confirmed that the central high-density region in C. anna contains a fovea, but not the temporal area. We found no evidence of a second, less well-developed fovea located close to the temporal retina margin. The central and temporal areas of high neuron density allow for increased spatial resolution in the lateral and frontal visual fields, respectively. Increased resolution in the frontal field in particular may be important for mediating feeding behaviors such as aerial docking with flowers and catching small insects.

(c) 2015 S. Karger AG, Basel

\section{Introduction}

Hummingbirds (Trochilidae: Aves) are a group of small, highly specialized New World birds. Most species weigh between 2.5 and $6.5 \mathrm{~g}$ [del Hoyo et al., 1999] and are dependent on the nectar of ornithophilous (bird-pollinated) flowering plants for survival. Hummingbirds are capable of high-precision hovering flight, which allows them to dock with flowers and insert their long, thin beaks in and out flowers with pin point accuracy [Lee et

\section{KARGER 125\%}

C 2015 S. Karger AG, Basel

0006-8977/15/0864-0176\$39.50/0
Thomas J. Lisney

School of Animal Biology and The Oceans Institute The University of Western Australia

35 Stirling Highway, Crawley, WA 6009 (Australia)

E-Mail tomlisney@gmail.com 
al., 1991; Altshuler and Dudley, 2002; Healy and Hurly, 2006]. As well as their ability to sustain hovering flight, which is unique among birds [Altshuler and Dudley, 2002], hummingbirds can also fly at high speeds and are extremely maneuverable, being able to fly upside down and backwards [Greenewalt, 1960; del Hoyo et al., 1999; Healy and Hurly, 2006; Warwick et al., 2012].

Like most birds, hummingbirds are diurnal (although some species may be active before dawn and after sunset) [del Hoyo et al., 1999]. Vision is considered the primary sensory modality used to gather information from the environment in order to guide their high speed, high precision flight and feeding behavior, as well as other tasks, such as identifying the most profitable flowers (i.e. flowers containing larger amounts of nectar) in a foraging patch [George, 1980], and in the detection of mates, conspecific competitors, and potential predators. However, in general very little is known about hummingbird visual systems. Moreover, much of what we do know is limited to hummingbird spectral sensitivity and color vision, which in hummingbirds extends into the ultraviolet [Goldsmith and Goldsmith, 1979; Goldsmith, 1980; Goldsmith et al., 1981, 1984; Chen et al., 1984; Herrera et al., 2008; Ödeen and Håstad, 2010]. The focus on these specific aspects of visual perception may be because of interest in the historical supposition that hummingbirds are preferentially attracted to certain colors of flowers (i.e. red) [Grant, 1966; Miller and Miller, 1971; Goldsmith and Goldsmith, 1979; Altshuler, 2003] and also because hummingbirds themselves display a vivid iridescent body coloration [Greenewalt et al., 1960], which is probably associated with intraspecific communication and sexual selection [Stiles, 1982; Herrera et al., 2008; Parra, 2010; Meadows et al., 2012]. Interestingly, recent work has revealed specializations in the parts of the brain in hummingbirds that are concerned with another aspect of visual perception, namely processing optic flow [Iwaniuk and Wylie, 2007]. In birds, the pretectal nucleus lentiformis mesencephali (LM) is vital for the processing of optic flow and generation of the optokinetic response [Gioanni et al., 1983; McKenna and Wallman, 1985; Winterson and Brauth, 1985; Wylie and Crowder, 2000]. This in turn serves to stabilize the retinal image and reduce the confounding effects of motion blur [Waespe and Henn, 1987]. In hummingbirds, the LM is significantly enlarged compared to other birds, which has been attributed to the high demands placed on processing optic flow during hovering flight [Iwaniuk and Wylie, 2007]. Recently, in a very elegant behavioral study, Goller and Altshuler [2014] showed that hummingbirds do indeed use optic flow to control hovering.

Hummingbird Vision
Despite interest in hummingbird visual systems and the aforementioned advances in our understanding of both color vision and neural specializations associated with the processing of optic flow, surprisingly little is known about retinal organization in hummingbirds. Based on macroscopic observations of preserved eyes, Wood [1917] described the retina of Anna's hummingbird (Calypte anna) as having 2 foveae, a large and relatively deep central fovea, and a smaller, shallower fovea positioned very close to the temporal margin of the retina (fig. 4b). More recently, Lee et al. [1991] described the retina of another species, the sparkling violetear (Colibri coruscans), as also having central and temporal foveae. However, Lee et al. [1991] presented no evidence of having actually assessed retinal organization in this species directly, and so it is unclear whether they did so or whether they simply extrapolated from Wood [1917]. Therefore, to our knowledge there have been no attempts to confirm the presence of retinal specializations in hummingbirds as described by Wood [1917] through topographic analysis of either the photoreceptor or retinal ganglion cell (RGC) distributions.

The aim of this study was to assess eye morphology and the topographic distribution of neurons in the RGC layer in hummingbirds, using retinal whole mounts. We have previously employed this approach successfully to investigate the visual systems of gamefowl [Lisney et al., 2012a], owls [Lisney et al., 2012b], waterfowl [Lisney et al., 2013a], and vultures [Lisney et al., 2013b]. Eye morphology, as determined from basic measurements of cornea size relative to eye size, has proved to be useful when comparing eyes from different species because relative cornea size is an excellent predictor of activity pattern in birds [Hall and Ross, 2007; Lisney et al., 2012a, b] as well as other vertebrates [Walls, 1942; Hughes, 1977; Kirk, 2004, 2006; Hall, 2008; Veilleux and Lewis, 2011]. Similarly, studies of retinal topography are informative because they serve to both identify and quantify specialized areas of high neuron density (i.e. areae, foveae, and visual streaks) [Hughes, 1977; Collin, 1999, 2008]. The position of these specializations in the retina reveals which part or parts of the visual field are sampled with increased spatial resolving power (SRP) and are thus of particular importance for survival tasks such as location of food and mates, predator surveillance, and obstacle avoidance. In addition to our aforementioned studies, recently a large number of retinal topography studies have revealed important information about retinal organization and evolution in a wide range of birds including waterfowl [Fernández-Juricic et al., 2011a; Lisney et al., 2013a], pen- 
Table 1. List of the hummingbird species surveyed in this study

\begin{tabular}{lll}
\hline Species & Common name & $\begin{array}{c}\text { Total eyes } \\
\text { examined, } \mathrm{n}\end{array}$ \\
\hline Amazilia tzacatl & Rufous-tailed hummingbird & 10 \\
Calypte anna & Anna's hummingbird & 12 \\
Phaethornis superciliosus & Long-tailed hermit & 4 \\
Selasphorus rufus & Rufous hummingbird & 1 \\
Thalurania colombica & Crowned wood nymph & 2 \\
\end{tabular}

guins [Coimbra et al., 2012], parrots [Coimbra et al., 2014a], and a variety of passerines [Coimbra et al., 2006, 2009; Fernández-Juricic et al., 2011a; Moore et al., 2013, 2015; Coimbra et al., 2014b]. Here, as well as providing detailed descriptions of eye morphology and retinal topography in a range of hummingbird species, we tested the following two predictions. First, as hummingbirds are diurnal, we predicted that they would have cornea size:eye size ratios similar to those found in other diurnal birds, such as vultures, pigeons and falcons. Second, following the macroscopic observations of Wood [1917], we predicted that the retinal topography of hummingbirds would feature a central, well-developed fovea and a second, temporal fovea located close to the retinal margin. One of the species we sampled was C. anna, which thus allowed us to directly compare our results with those of Wood [1917] for the same species.

\section{Materials and Methods}

\section{Specimens}

Eyes from 5 species of hummingbird (table 1) were used in this study. All of the eyes were collected by other researchers and donated to us. For further details, see Ward et al. [2012]. Eyes were removed from the head and immersion fixed and stored in $4 \%$ paraformaldehyde in $0.1 \mathrm{M}$ phosphate buffer ( $\mathrm{PFA}, \mathrm{pH}=7.4$ ).

\section{Eye Morphology}

Prior to the dissection of each eyeball, we measured the transverse diameters of both the eye and the cornea along 2 perpendicular planes using digital calipers, as described by Lisney et al. [2012b, 2103b]. These measurements were used to calculate the mean corneal diameter $(\mathrm{C})$, the mean transverse eye diameter $(\mathrm{T})$, and the C:T ratio, a measure of cornea size relative to the total size of the eye [Kirk, 2006]. All of the hummingbird eyes available to us had collapsed due to the loss of internal fluids postmortem [Ritland, 1982; Kirk, 2004]. We did attempt to 'reinflate' some of the eyes by injecting them with fixative using a syringe and a smallgauge needle [see Ritland, 1982; Kirk, 2004, 2006; Hall and Ross, 2007], but we suspected that this may have damaged the retinas (see below). Moreover, there are no significant differences between
C:T calculated from corneal and eye diameter measurements made before and after reinflation in birds [Lisney et al., 2012b, 2013a, b]. Therefore, we are confident that our measurements still provide realistic measures of cornea size relative to eye size in the hummingbird species we assessed.

\section{Preparation of Retinal Whole Mounts}

Upon dissection of the eyes, we discovered that the majority of the retinas were not suitable for whole mounting. This was because the eyes had not been well preserved, and thus the retinas were not suitably fixed, or alternatively because they had been in fixative for too long and thus had become very brittle and/or heavily folded, meaning that they could not be flattened without breaking apart. The retinas from the eyes that we tried to inflate had broken into many small pieces. Ultimately, we were able to successfully whole mount 5 retinas, 3 for $C$. anna and 1 each for Amazilia tzacatl and Phaethornis superciliosus (although we were not able to get a complete count from the $P$. superciliosus whole mount, as described below). The whole mounts were prepared using established methods for avian retinas [e.g. Coimbra et al., 2006, 2009; Lisney et al., $2012 \mathrm{a}, \mathrm{b}]$. We were able to orient the whole mounts using the position of the pecten, which is located in the ventral retina [Wood, 1917]. Pieces of retinal pigment epithelium that could not be removed from the retinas manually were bleached with $10 \%$ hydrogen peroxide in 0.1 phosphate buffer at room temperature [Coimbra et al., 2006]. Whole mounts were stained for Nissl substance using $0.1 \%$ cresyl violet $(\mathrm{pH}=4.3$ ) [Stone, 1981; Lisney et al., 2012a, b, 2013a, b]. We determined the shrinkage of the whole mounts caused by the staining process by measuring the outline of each whole mount before and after staining from scaled digital photographs [Lisney et al., 2012a, b, 2013a, b], using the publicdomain NIH image program ImageJ [Rasband, 1997-2015]. Shrinkage was minimal, averaging $5 \%$, and was confined to the margins of the whole mount and along the edges of the radial relieving cuts or tears [Stone, 1981; Coimbra et al., 2006].

\section{Stereology}

The topographic distribution and total number of neurons in the RGC layer was determined using stereology. Specifically, we used the optical fractionator method [West et al., 1991] modified for the analysis of retinal whole mounts by Coimbra et al. [2009, 2012]. Using the two microscope imaging systems already described by Lisney et al. [2013a], digital photographs of the RGC layer were taken at regularly spaced intervals across the entire surface of each whole mount using a systematic random sampling protocol and a sampling grid size of $283 \times 283 \mu \mathrm{m}$. This approach resulted in between approximately 250 and 350 sites being sampled for each whole mount (table 2). Neuron counts were then made from the digital photographs. An unbiased counting frame measuring $35 \times 35 \mu \mathrm{m}$ was placed in the center of each photograph using ImageJ. Nissl-stained neurons were counted provided they either lay entirely within the counting frame or they touched an acceptance line without also touching a rejection line [Gundersen, 1977]. We did not attempt to differentiate between RGC and displaced amacrine cells also found in the RGC layer because we could not reliably distinguish between the two neuron types using cytological criteria in the areas of high neuron density [also see Coimbra et al., 2006, 2009, 2014b; Lisney et al., 2012a, b, 2013a, b]. However, presumptive glial cells, identified on the basis of their small size, dark staining and small, round or elongated shape [Hughes, 
Table 2. Stereological parameters and estimates of the total number of neurons in the RGC layer in 3 species of hummingbird

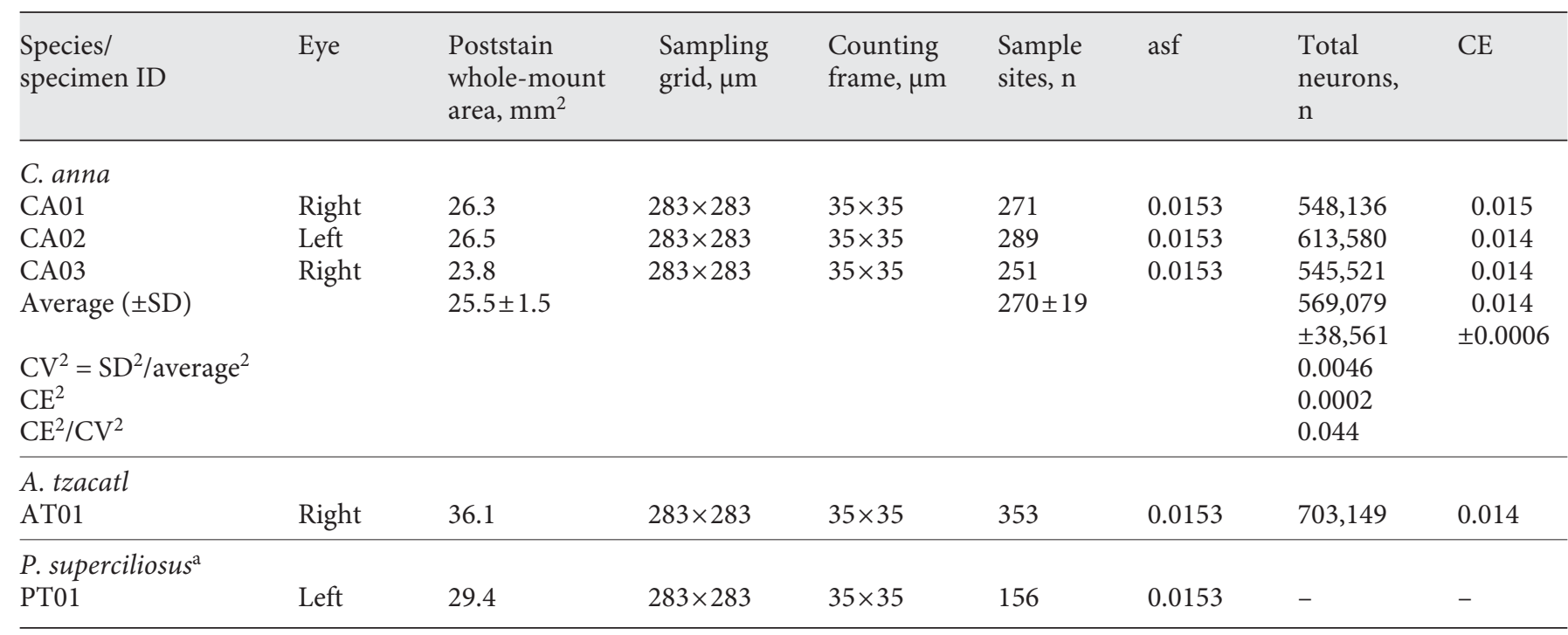

asf $=$ Area sampling fraction. ${ }^{\text {a }}$ The $P$. superciliosus whole-mount count could only be partially determined and so no estimate of the total number of neurons or the CE is provided.

1985; Wathey and Pettigrew, 1989; Coimbra et al., 2009, 2014b], were not included in the counts (fig. 2). Across the majority of the retinas, the RGC layer consisted of a single layer of neurons. However, in high-density areas in the central retina we found 2-4 sublaminae. For sample sites in these areas, a series of digital photographs focused on each sublamina was taken, thus creating an image stack through the z-axis [Lisney et al., 2012b]. Neuron counts were then made from each photograph in a stack as described above, taking care to cross-reference against the other photographs within the stack to avoid double counting. The validity of the counts made from photographs was confirmed by viewing the whole mounts directly under the microscope while carefully focusing through the RGC layer [Bravo and Pettigrew, 1981; Coimbra et al., 2014a, b].

According to the modification of the optical fractionator for retinal whole mounts, the whole mount is considered to be a single section and the height of the optical dissector is considered to be the same as the thickness of the RGC layer [Coimbra et al., 2009, 2012]. Therefore, both the section sampling fraction and the thickness sampling fraction are set to 1 . Thus, in order to determine the total number of neurons in the RGC layer for each whole mount, the sum of the total number of neurons counted was multiplied by the inverse of the area sampling fraction [Coimbra et al., 2009, 2012], where the area sampling fraction is the area of the counting frame divided by the area of the sampling grid. In stereology, the coefficient of error (CE) is used as measure of the precision of an estimate of the total number of objects (i.e. cells) within a structure, with $\mathrm{CE} \leq 0.1$ considered highly reliable [West, 2012]. Here we calculated CE using Schaeffer's estimator for a 1-stage systematic sample [Schaeffer et al., 1996] for nonhomogeneous distributions [Schmitz and Hof, 2000]. The CE values were very low for all of our whole mounts $(\leq 0.015$; table 2$)$, indicating that our estimates of total neuron number are robust.
In order to map the topographic distribution of neurons in the RGC layer in each of our whole mounts, the neuron counts at each sampling site were converted to densities $\left(\right.$ cells $\cdot \mathrm{mm}^{-2}$ ). Isodensity contour plots were made using DeltaGraph 6 software (Red Rock Software, Salt Lake City, Utah, USA) [Ahnelt et al., 2006; Schiviz et al., 2008; Lisney et al., 2012b, 2013a, b]. The scaled, correctly oriented poststain outline of each whole mount, traced from a digital photograph (see above), was then superimposed on top of each contour plot in order to complete the topographic maps.

\section{Spatial Resolving Power}

In some previous studies on birds, peak RGC densities around the fovea have been used to estimate the upper limits of SRP in foveate species [e.g. Moroney and Pettigrew, 1987; Fernández-Juricic et al., 2011b; Lisney et al., 2013b; Moore et al., 2013, 2015; Krabichler et al., 2015]. Recently, however, Coimbra et al. [2014a, b, 2015] pointed out that this approach is problematic. At the center of a fovea is the 'foveola' from which the inner retinal layers (including the RGC layer) can be either completely (e.g. primates and some birds with deep foveas [Fite and Rosenfield-Wessels, 1975; Curcio and Allen, 1990; Wässle et al., 1990]) or partially (e.g. some birds with shallow foveas [Coimbra et al., 2014a, b]) displaced, thus creating a foveal depression or 'pit' [Provis et al., 2013]. In order to correct for the centrifugal displacement of the RGC and to determine the actual RGC density that corresponds with the foveal cone array, the lengths of the Henle fibers (cone fibers) are required [Wässle et al., 1990]. However, even if it were possible to allow for this displacement, if it is assumed that foveate birds possess a primate-like midget system in the central fovea [Fite and RosenfieldWessels, 1975; Coimbra et al., 2014a, b, 2015], where RGC densities may exceed cone densities by between 2 and 4 to 1 [Wässle et al., 1990; Drasdo et al., 2007], then the peak RGC densities around the fovea may not be the best indicators of the limits of spatial resolu- 


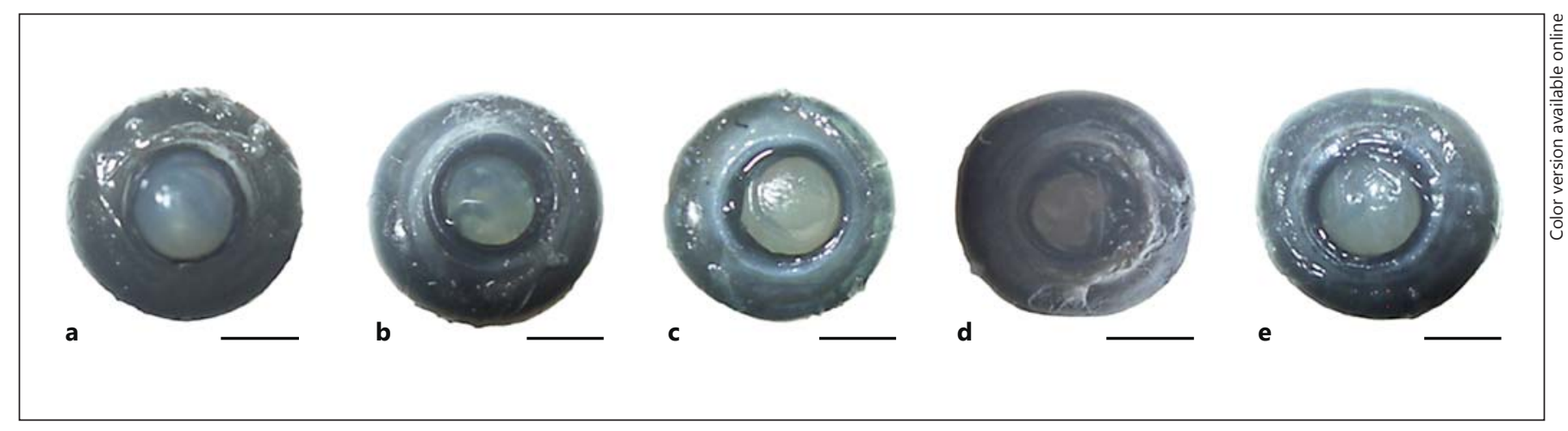

Fig. 1. Eye morphology in hummingbirds. Photographs of excised eyes from A. tzacatl (a), C. anna (b), P. superciliosus (c), Selasphorus rufus (d), and Thalurania colombica (e). Note the similarity in the size of the cornea relative to the whole eye in all 5 species. Scale bars $=2 \mathrm{~mm}$.
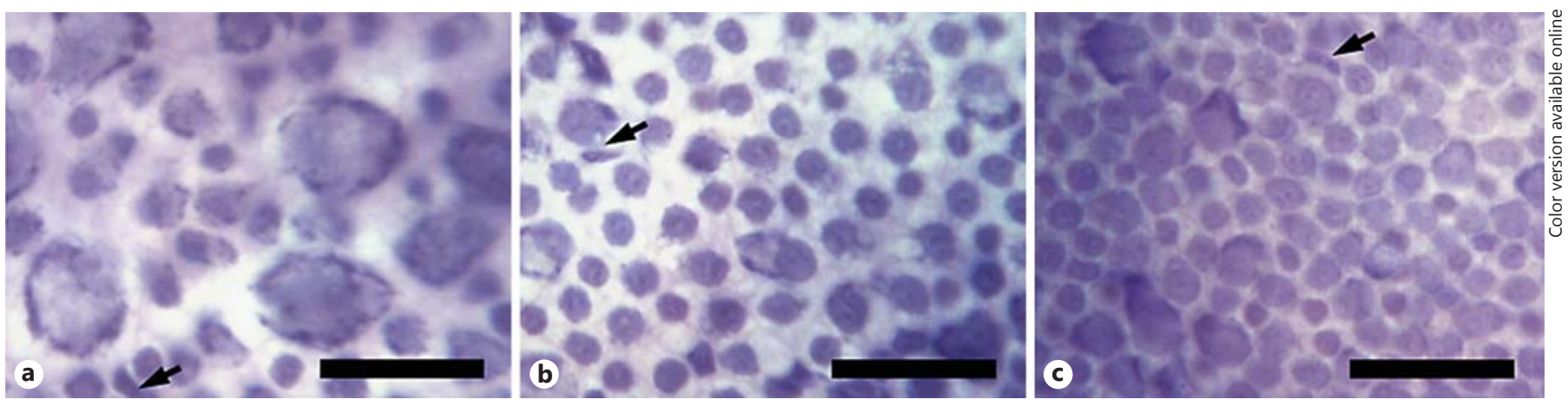

Fig. 2. High-magnification digital photographs showing Nisslstained neurons in the RGC layer in P. superciliosus. Cells in the far naso-dorsal periphery $\left(\sim 14,000\right.$ cells $\left.\cdot \mathrm{mm}^{-2}\right)(\mathbf{a})$, the ventrocental retina $\left(\sim 25,000\right.$ cells $\left.\cdot \mathrm{mm}^{-2}\right)(\mathbf{b})$, and the central retina close to the area of peak cell density $\left(\sim 44,000\right.$ cells $\left.\cdot \mathrm{mm}^{-2}\right)$ (c). Glial cells, which were not included in the neuron counts, are marked with arrows. Scale bars $=20 \mu \mathrm{m}$. tion. Indeed, in the foveae of both primates and diurnal birds of prey, it appears that the cone density sets the limits of spatial resolution [Reymond, 1985, 1987; Wässle and Boycott, 1991]. Following the recommendations of Coimbra et al. [2014a, b], here we only estimated SRP for afoveate regions of high neuron density for our A. tzacatl, C. anna, and P. superciliosus whole mounts. This was done using the correspondent peak neuron density values and an estimate of the posterior nodal distance (PND) of the hummingbird eye, following the sampling theorem [Snyder and Miller, 1977; Williams and Coletta, 1987] as described in detail by Hart [2002]. In diurnal animals such as hummingbirds, the PND is approximately 0.67 times the eye axial length [Pettigrew et al., 1988]. As we were not able to directly measure the axial length of any of our hummingbird eyes, we used data on axial eye length taken from Ritland [1982] (table 3). The anatomical estimates of SRP that we present should be considered theoretical upper limits [Pettigrew et al., 1988; Collin and Pettigrew, 1989], firstly because it is not known whether all of the neurons in the area of peak density are indeed RGC and secondly because, even if all of the neurons are RGC, we do not know whether they are all involved in the discrimination of fine detail [Hughes, 1977; Wässle, 2004].

\section{Retinal Cross Sections}

Two C. anna retinas (one left and one right) were sectioned in order to visualize the retina in cross section. After removing the cornea, lens, and vitreous, the remaining eyecups were embedded in gelatin and sectioned in the horizontal plane at $30 \mu \mathrm{m}$ using a sledge microtome (Leica SM2000R; Concord, Ont., Canada). Sections were collected in $0.1 \mathrm{M}$ phosphate-buffered saline using a fine paintbrush and mounted onto gelatinized slides. After air-drying, the slides were stained with $0.1 \%$ cresyl violet, dehydrated through a graded ethanol series, cleared in CitriSolv (Fisher Scientific, Ottawa, Ont., Canada), and coverslipped with Permount (Fisher Scientific). Sections were viewed and photographed with a $\times 2$ objective on a compound microscope (Nikon Eclipse 80i; Mississauga, Ont., Canada) equipped with a MicroFire digital camera, and using Picture Frame 2.5 image processing software (both from Optronics, Goleta, Calif., USA). The length of the RGC layer was measured from scaled digital photographs using ImageJ for every other section, except in a band across the central retinal meridian stretching from the dorsal pole of the central fovea to approximately a third of the distance along the length of the pecten, measured from the superior pole, where every section was measured. 
Table 3. Neuron densities and optical parameters used to estimate the theoretical peak SRP in 3 species of hummingbird

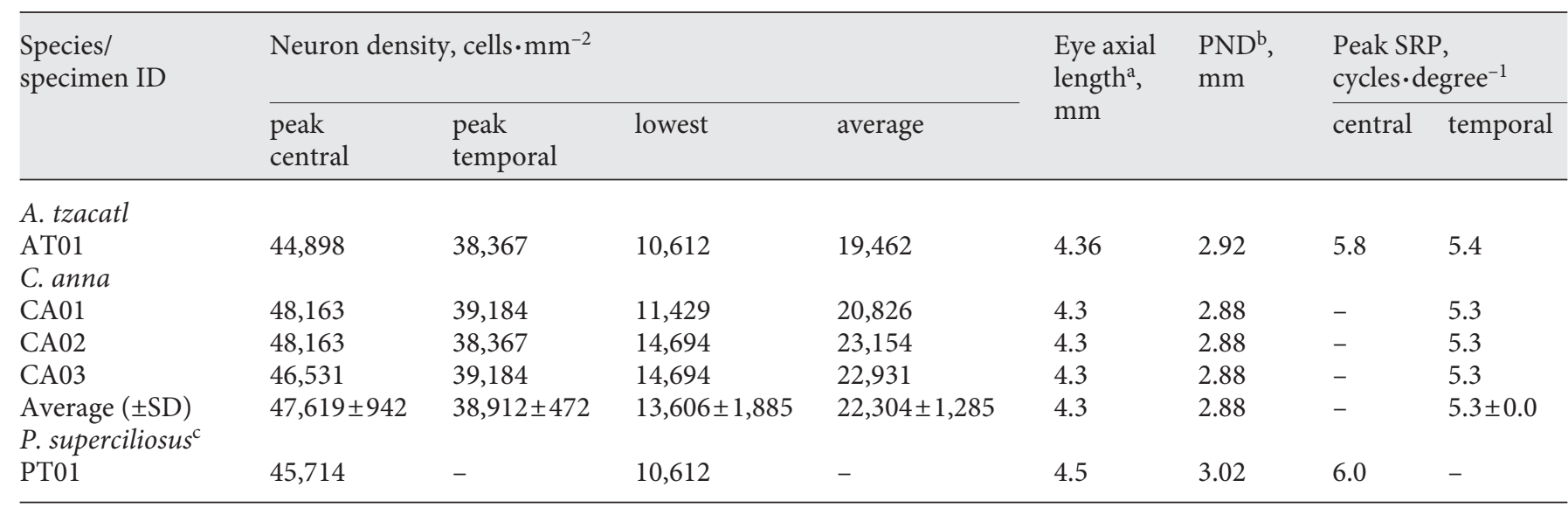

Peak neuron densities are presented for the central and temporal high-density areas, except in C. anna. In this species, we did not calculate SRP for the foveated central high-density area (see Materials and Methods for explanation). The lowest and average neuron densities are for each retina as a whole. Estimates of peak SRP are based on the peak neuron densities in the central area and temporal areas. PND $=$ Posterior nodal distance. ${ }^{\text {a }}$ Eye axial length values from Ritland [1982]. For $A$. $t z a c a t l$, the axial length value is the average of the values Ritland [1982] presented for 4 other species of the same genus (i.e. A. beryllina, A. fimbriata, A. lactea, and A. vesicolor). ${ }^{\mathrm{b}}$ Estimated assuming that the PND is 0.67 times the eye axial length [Pettigrew et al., 1988]. ${ }^{\mathrm{c}}$ The $P$. superciliosus whole-mount count could only be partially determined. Therefore, no estimates of peak neuron density in the temporal area or the average neuron density across the whole retina are provided for this species.

The position and size of retinal structures such as the central fovea and the pecten were also recorded, allowing the retinas to be reconstructed in 2 dimensions.

\section{Results}

\section{Eye Morphology}

Hummingbird eyes are small, with mean transverse diameters of only 5-6 $\mathrm{mm}$ (table 4 ; fig. 1 ). The eyes from A. tzacatl, P. superciliosus, and T. columbica were slightly larger than those from C. anna and S. rufus. The C:T ratios calculated for the 5 species were similar, all being around 0.5 .

\section{Total Number of Neurons in the RGC}

A summary of our stereological sampling of the RGC layer in the 3 species is given in table 2. The P. superciliosus retina was heavily folded in some areas, meaning that we were not able to count neurons according to our stereological sampling protocol across approximately two fifths (in the dorsal and temporal areas) of the whole mount. Therefore, we have not presented an estimate of the total number of Nissl-stained neurons in the RGC for this species. The $C$. anna whole mounts were approximately 1.4 times smaller than the A. tzacatl whole mount,
Table 4. Eye morphology in 5 species of hummingbird

\begin{tabular}{lclll}
\hline Species & Eyes, n & C & T & C:T \\
\hline A. tzacatl & 10 & $2.92 \pm 0.22$ & $5.90 \pm 0.31$ & 0.49 \\
C. anna & 12 & $2.67 \pm 0.19$ & $5.33 \pm 0.49$ & 0.50 \\
P. superciliosus & 4 & $3.10 \pm 0.11$ & $6.11 \pm 0.20$ & 0.51 \\
S. rufus & 1 & 2.69 & 5.28 & 0.51 \\
T. colombica & 2 & 3.11 & 6.38 & 0.49 \\
\hline
\end{tabular}

Values are presented as millimeters \pm SD unless otherwise stated.

and our estimates of the total number of neurons in the RGC layer for these two species varied accordingly, with C. anna and A. tzacatl having $\sim 570,000$ and 700,000 neurons, respectively. As already mentioned, the $\mathrm{CE}$ values were very low for all of our whole mounts (i.e. 0.0140.015 ; table 2). Moreover, the variance introduced by the stereological procedures used should not be greater than $50 \%$ of the observed group variance [coefficient of variation $(\mathrm{CV})^{2}$ ], resulting in a $\mathrm{CE}^{2} / \mathrm{CV}^{2}$ ratio of less than 0.5 [Slomianka and West, 2005]. For C. anna, the only species for which we analyzed multiple whole mounts, the $\mathrm{CE}^{2} / \mathrm{CV}^{2}$ ratio (0.044) was much lower than 0.5 (table 2). 
Fig. 3. Retinal topography in hummingbirds. Representative isodensity contour maps illustrating the topographic distribution of neurons in the RGC layer for $A$. tzacatl (right retina) (a) and C. anna (left retina) (b). The topographic map for $C$. anna has been flipped horizontally to facilitate comparisons between the two species. The shaded density scales, which differ slightly between the two species, represent $\mathrm{n} \times 10^{2}$ cells $\cdot \mathrm{mm}^{-2}$. The irregular black shape in $\mathbf{a}$ and $\mathbf{b}$ represents the position of the pecten. $\mathrm{T}=$ Temporal; $\mathrm{V}=$ ventral. Scale bars $=2.5 \mathrm{~mm}$. c, d Density profiles for neurons in the RGC layer measured along a naso-temporal transect $\left(\mathrm{a}-\mathrm{a}^{\prime}\right)$ across the retina in the $A$. tzacatl whole mount (c) and a naso-temporal transect $\left(\mathrm{b}-\mathrm{b}^{\prime}\right)$ in the C. anna whole mount (d). The arrows in $\mathbf{a}$ and $\mathbf{b}$ mark the position of the transects, which run through the two highcell-density areas in each retina, the central area (CA) and the temporal area (TA). The density scale on the $y$-axes represents $n \times$ $10^{2}$ cells $\cdot \mathrm{mm}^{-2}$.

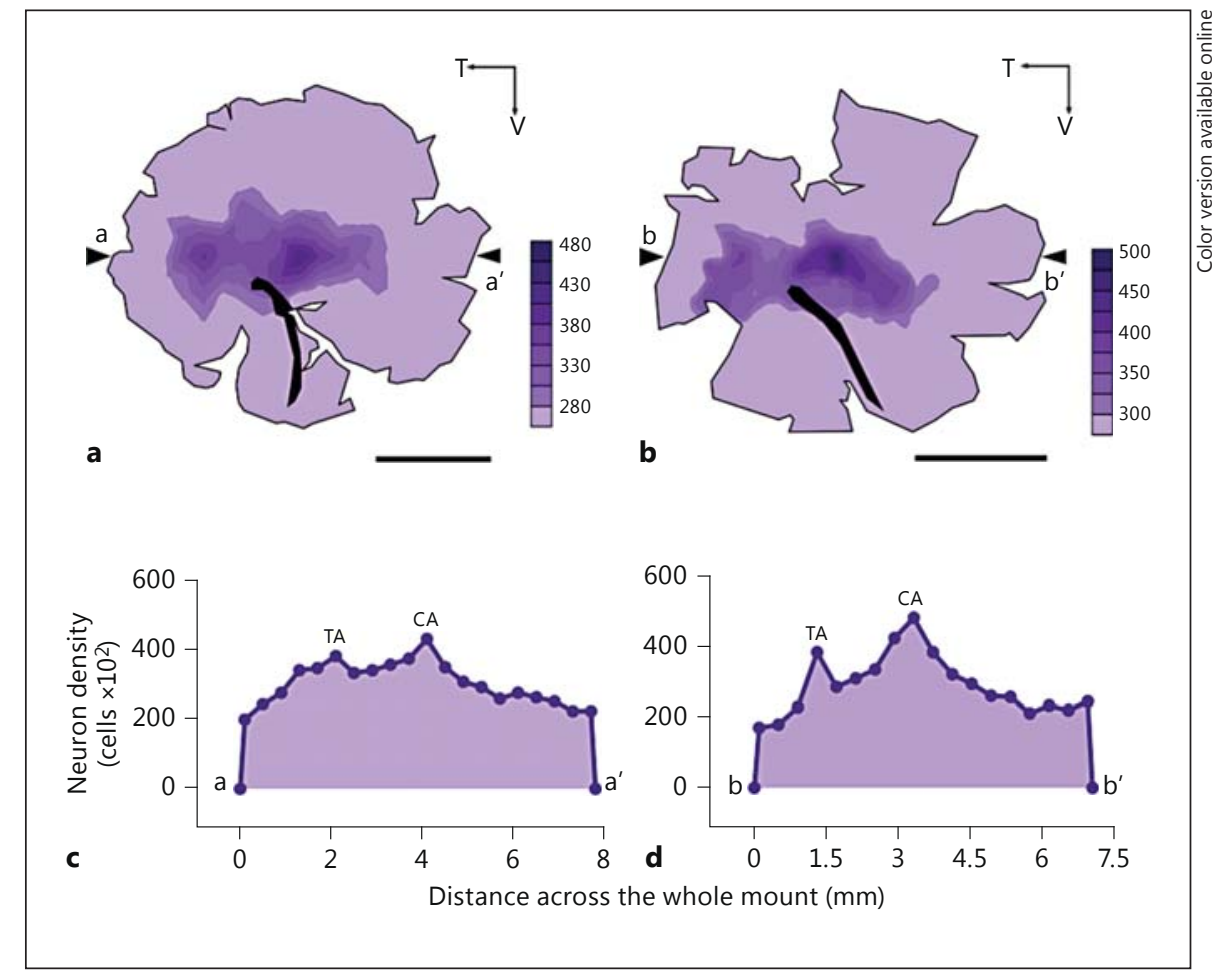

\section{Retinal Topography, Neuron Densities, and SRP}

The density of neurons in the RGC layer varied across the retina in all 3 species (fig. 2). Isodensity contour maps constructed for A. tzacatl and C. anna revealed that retinal topography is similar in these species (fig. 3a, b). Both species have a central region of high neuron density, located slightly dorso-nasal to the superior pole of the pecten, where densities reach $\sim 45,000$ cells $\cdot \mathrm{mm}^{-2}$ (also see table 3). As mentioned above, we were not able to sample the entire P. superciliosus whole mount. However, we did detect a central area of high neuron density in the same location as in the A. tzacatl and C. anna whole mounts, which contained a comparable peak density (table 3 ). A second region of high neuron density was apparent in both A. tzacatl and C. anna, positioned temporal to the central high-density area. In this second high-density area, the densities were not as high as those found in the central area, reaching up to 39,000 cells $\cdot \mathrm{mm}^{-2}$ (table 3 ). The two high-density areas were connected by a short band of increased neuron density or visual streak. The positions of the 2 areas of peak density in the A. tzacatl and $C$. anna retinas are further illustrated in a frequency histogram showing how neuronal density varies as a function of eccentricity along a horizontal transect through the areas of high density (fig. $3 c$, d). From the whole mounts themselves we could not detect a foveal pit associated with either of these two high-density regions in any of the retinas.

Overall, the peak, lowest, and average neuron densities and SRP were similar among species, with C. anna having slightly higher neuron densities than the other 2 species (table 3 ). In all 3 species, the lowest densities were found in the far retinal periphery. The density gradients between the peak and lowest densities (table 3 ) were similar across species, ranging from 3.5 in C. anna to 4.2 and 4.3 in A. tzacatl and P. superciliosus, respectively. Though not assessed quantitatively, we observed that the neurons in the peripheral retina were more heterogeneous in terms of size and shape compared to the relatively homogenous population of small, round neurons found in the central retina around the area of peak density (fig. 2).

As mentioned previously, using peak RGC densities around the fovea to estimate SRP in birds is problematic [Coimbra et al., 2014a, b, 2015]. As the central high-density area in C. anna contains a fovea (see below), we did not calculate SRP for this high-density area in this species. No evidence of a fovea was found in the temporal highdensity area in any of the 3 species or in the central retina of $A$. tzacatl and P. superciliosus. Our estimates of SRP are presented in table 3. In A. tzacatl and P. superciliosus, SRP 
Fig. 4. Retinal cross sections and reconstructions in C. anna. a Reconstruction of the right retina, using 90 sections cut on the horizontal plane. The reconstructed retina is approximately circular, with the outer boundary representing the margin of the retina at the ora serrata. The positions of the pecten and the central fovea are clearly indicated. The dashed lines represent the upper and lower boundaries of the area of the retina for which every section was measured. Outline of these boundaries; every other section was measured. $\mathrm{T}=$ Temporal; $\mathrm{V}=$ ventral. For comparison, the drawing of Wood [1917] (b) of a right C. anna retina based on macroscopic observations of preserved material is presented. The positions of the central fovea and pecten are in close agreement with our retinal reconstruction shown in a. The drawing of Wood [1917] also depicts a second, smaller and shallower fovea located very close to the temporal margin of the retina and approximately in line with the superior pole of the pecten (arrow), which we found no evidence of in this study. c Entire section across the right retina that passes through the middle of the central fovea (arrow). Scale bar $=1 \mathrm{~mm}$. The position of the section with respect to the whole retina is illustrated by transect $\mathbf{a}-\mathrm{a}^{\prime}$ in a. d Close-up of the central convexiclivate fovea. Scale bar $=300 \mu \mathrm{m}$.

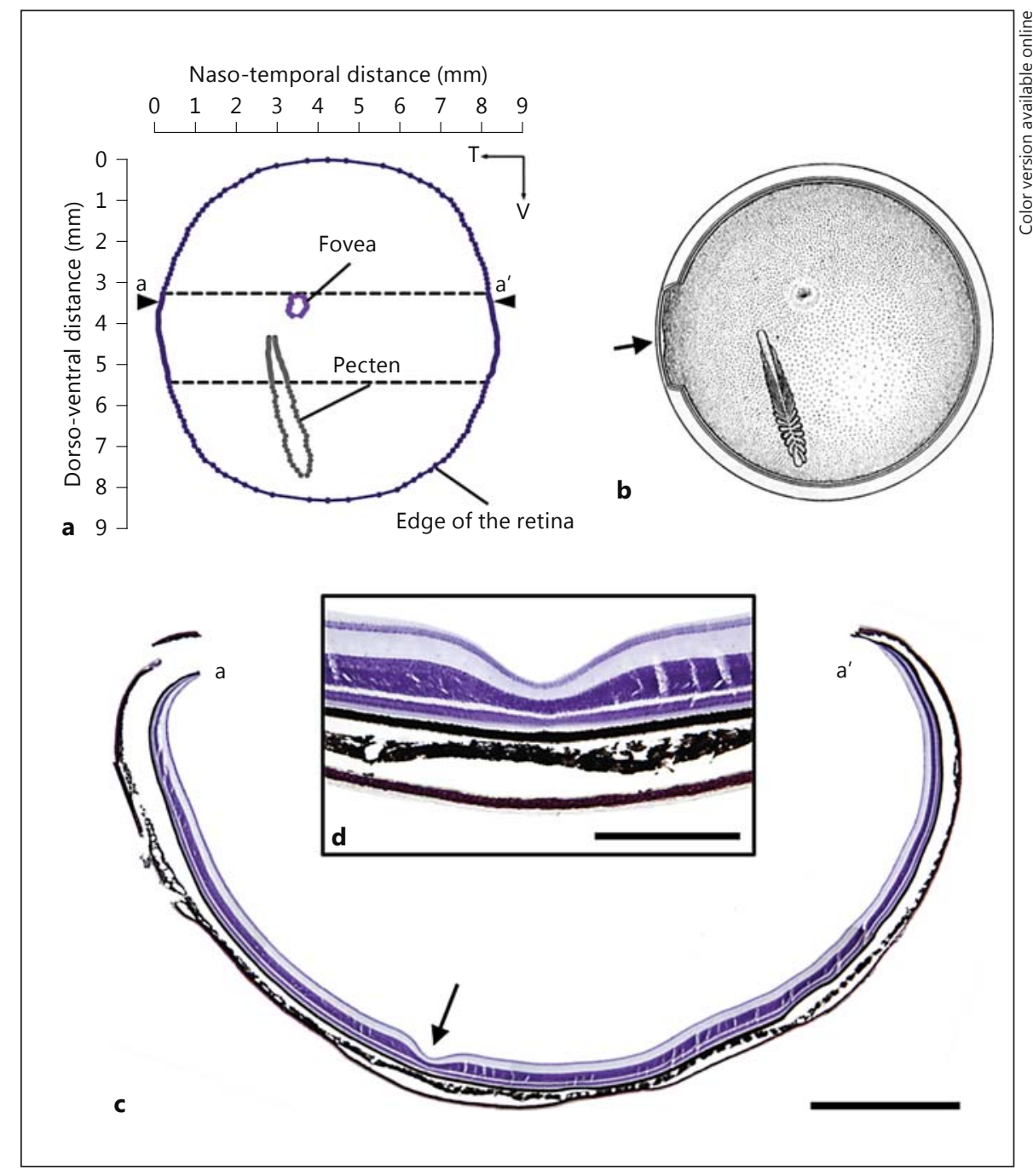

for the central high-density area were comparable (5.8-

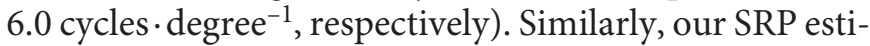
mates for the temporal high-density area in A. tzacatl and C. anna (5.3 and 5.4 cycles $\cdot$ degree $^{-1}$, respectively) were also very similar.

\section{Retinal Cross Sections}

Two C. anna retinas were reconstructed from cross sections. The right retina was reconstructed from $90 \mathrm{sec}-$ tions and the left from 86 . The reconstruction of the right retina is shown in figure 4 . The sections revealed the presence of a central fovea in C. anna, located slightly dorsonasal to the superior pole of the pecten, which is the same location as that of the peak neuron density area we identified in the whole mounts (described above). The sections showed no evidence of a second, temporal fovea either in the second high-density area revealed by the isodensity contour maps or close to the temporal margin of the retina where Wood [1917] reported the presence of a temporal fovea in this species.

\section{Discussion}

In this study, we evaluated eye morphology in 5 species of hummingbird, and for 2 of these species we used stereology and retinal whole mounts to assess the topographic distribution of neurons in the RGC layer. Despite having access to 2 or more eyes for each species, we were only able to whole mount and analyze 3 retinas for C. anna and 1 for $A$. tzacatl. Therefore, we were not able to account for individual variation in this species. However, in C. anna, 


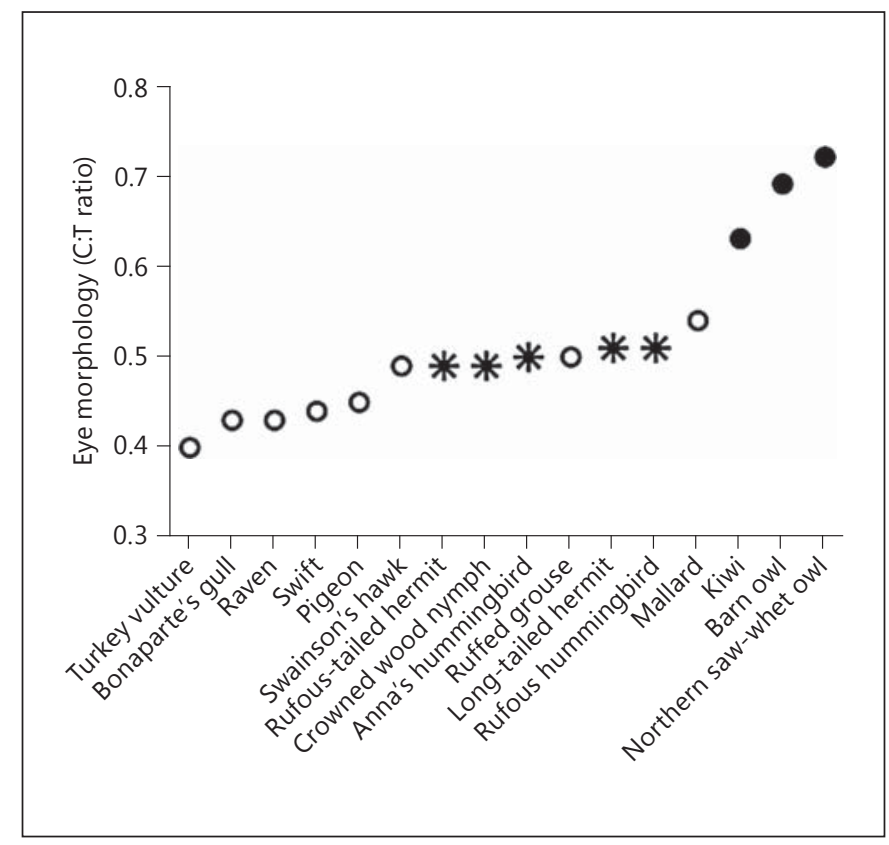

Fig. 5. Eye morphology (expressed as the ratio of the mean corneal diameter to the mean transverse eye diameter, i.e. the C:T ratio), in hummingbirds (asterisks) in comparison to other diurnal (open circles) and nocturnal (closed circles) birds. Sources of information for C:T values: turkey vulture [Lisney et al., 2013b]; ruffed grouse [Lisney et al., 2012a]; hummingbirds, this study; mallard [Lisney et al., 2013a]; kiwi [Martin et al., 2007]; barn owl and northern saw-whet owl [Lisney et al., 2012b]; all other species [Lisney et al., unpubl. data].

retinal topography, along with the numbers and densities of neurons, was very consistent among individuals (tables $2,3)$, which gives us confidence that our results for $A$. tzacatl are indeed representative for this species. Moreover, in general among vertebrates there appears to be little variation across individuals of the same age or size class with regard to the topography of neurons in the RGC layer, as emphasized by the convention of presenting one representative retinal topography map for a given species. Only rarely are multiple maps for the same species presented in the same publication, and in these cases retinal topography is consistent across individuals of the same age or size class [Boire et al., 2001; Pettigrew et al., 2010, but see Coimbra et al., 2014b].

\section{Eye Morphology}

Hummingbirds are among the smallest of birds, and as eye size scales with body size in these animals [Ritland, 1982; Howland et al., 2004], it is no surprise that hummingbirds also have small eyes. The C:T ratios of around
0.5 that we found for all 5 species fall within the values previously documented for diurnal birds and are considerably lower than the ratios found in nocturnal species such as kiwis and owls, thus confirming our first prediction (fig. 5) [Hall and Ross, 2007; Martin et al., 2007; Lisney et al., 2012b, 2013b]. Therefore, it appears that, in terms of gross morphology, the eyes of the 5 hummingbird species investigated here are adapted for diurnal vision. In general, ratios that measure the size of the cornea relative to the eye, such as the $\mathrm{C}: \mathrm{T}$ ratio, have proven to be highly correlated with activity pattern in birds [Hall and Ross, 2007; Lisney et al., 2012b, 2013b], nonavian reptiles [Hall, 2008], and mammals [Hughes, 1977; Kirk, 2004, 2006; Veilleux and Lewis, 2011]. Higher ratios equate to an enlarged cornea relative to the size of the eye, which serves to increase the amount of light that can enter the eye when the pupil is maximally dilated and is thus hugely advantageous for nocturnal species active at low light levels [Walls, 1942; Land and Nilsson, 2002; Kirk, 2006]. In contrast, the relatively smaller corneas found in diurnal animals are an adaptation for improving visual acuity through increasing the size of the retinal image [Walls, 1942; Land and Nilsson, 2002; Kirk, 2006]. Cathemeral or crepuscular species tend to have relative cornea sizes that are intermediate between those of diurnal and nocturnal species [Walls, 1942; Kirk, 2004, 2006; Hall and Ross, 2007]. Some hummingbird species, such as members of the genus Coeligena, visit flowers in the early morning before sunrise [del Hoyo et al., 1999]. Therefore, it would be interesting to determine whether these more crepuscular hummingbirds have relatively larger corneas than their diurnal relatives.

\section{Topography of Neurons in the RGC Layer}

In this study we did not attempt to differentiate between RGC and the displaced amacrine cell population that is also found in the RGC layer. While acknowledging that other authors have used cytological and morphological criteria to differentiate between RGC and displaced amacrine cells in whole mounts from some avian species [e.g. Ehrlich, 1981; Hayes and Brooke, 1990; Hart, 2002; Dolan and Fernández-Juricic, 2010; Coimbra et al., 2012], in our experience is not possible to reliably distinguish between these two neuron types using such criteria in areas of high neuron density in the avian retinas that we examined [see Lisney et al., 2012a, b, 2013a, b]. This is because in these high-density areas the RGC become smaller and increasingly circular/ovoid (and thus appear more like amacrine cells) and the cell bodies themselves overlap considerably [Hayes, 1984; Boire et al., 2001; 
Hart, 2002; Coimbra et al., 2006, 2009]. Therefore, to avoid potential issues in differentiating amacrine cells from RGC, here we present retinal topography maps and data based on counts of all Nissl-stained neurons, as described above. In doing so, we accept that we have likely overestimated the true RGC densities in the hummingbird species we examined, due to inclusion of the displaced amacrine cell population. However, we do not consider this to be a major issue for two important reasons. Firstly, in a wide range of species from various vertebrate groups (including cartilaginous and bony fishes, turtles, birds, and mammals), in which RGC topography has been determined using both Nissl staining and retrograde labeling from the optic nerve or retino-recipient areas in the brain, the peak neuron densities and the overall retinal topography remain relatively similar despite inclusion of the displaced amacrine cells [Peterson and Ullinski, 1979; Bravo and Pettigrew, 1981; Collin, 1988; Collin and Pettigrew, 1988; Pettigrew et al., 1988; Chen and Naito, 1999; Bailes et al., 2006]. Secondly, because neuron counts are converted to densities and then reduced to the square root for the purposes of calculating SRP, a relatively large difference in peak neuron density values results in a small difference in terms of SRP [Pettigrew et al., 1988, 2010; Pettigrew and Manger, 2008; Ullmann et al., 2012].

The retinal topography in A. tzacatl and C. anna is very similar. It is characterized by the presence of 2 areas of high neuron density, i.e. one in the central retina and another located more temporally, which are connected by a visual streak. Of the two, the central area contains the highest neuron densities. In addition, in P. superciliosus, although we were unable to sample the entire retina, we also found a central area of high neuron density with a density value comparable to those of the other 2 species. These species are not particularly closely related within Trochiliidae (recent phylogenetic analyses have placed them in 3 separate clades [McGuire et al., 2007, 2014]). This could be taken as evidence that, overall, hummingbirds share a broadly similar pattern in retinal topography. However, there are over 300 species of hummingbirds and these birds are ecologically diverse [del Hoyo et al., 1999], so, until data become available for a broader range of species, it is unclear to what extent our results apply across hummingbirds.

Using cross sections, we were able to confirm that the central high-density area in C. anna is foveated, but not the temporal area. This refutes our second prediction that both the central and the temporal high-density areas contain foveae, at least for C. anna. As described above, we could not detect a fovea in any of our whole mounts. Although foveae have identified directly from whole mounts in a number of birds [e.g. Bravo and Pettigrew, 1981; Lisney et al., 2012b; Coimbra et al., 2014a, b, 2015], this is not always possible, for a variety of reasons. Foveal morphology may degrade particularly rapidly if there is any delay between death and fixation [Stone and Johnston, 1981]. These structures can also tear easily during the whole mounting and drying process [Bravo and Pettigrew, 1981], and they may be damaged by tears or poorly positioned radial cuts that are made in the retina to allow it to lie flat on a microscope slide. Foveae can also be obscured by the presence of small folds that can occur during fixation. We experienced a small degree of folding in the central retina in our hummingbird whole mounts which, while not enough to preclude or distort our neuron counts, was enough to hinder the unequivocal identification of a fovea. This may be a particular issue in retinas from species such as C. anna, where the fovea is relatively shallow compared to those in other birds [Slonaker, 1897; Fite and Rosenfield-Wessels, 1975; Reymond, 1985, 1987; Moroney and Pettigrew, 1987; Coimbra et al., 2006]. Although we do not have direct evidence to support this, the central area in A. tzacatl and P. superciliosus may also contain a shallow fovea, which we were not able to detect in whole mounts for these species. Support for this suggestion comes from the fact that the presence of a central fovea is a very common feature in the retinas of a diverse range of birds, including pigeons [Binggeli and Paule, 1969; Querubin et al., 2009], kingfishers [Slonaker, 1897; Moroney and Pettigrew, 1987], terns [Slonaker, 1897; Fite and Rosenfield-Wessels, 1975], swallows [Slonaker, 1897], passerines [Slonaker, 1897; Fite and RosenfieldWessels, 1975; Coimbra et al., 2006, 2009, 2014b; Moore et al., 2013, 2015], parrots [Coimbra et al., 2014a], falcons, eagles, and vultures [Slonaker, 1897; Fite and RosenfieldWessels, 1975; Frost et al., 1990; Inzunza et al., 1991; Lisney et al., 2013b]. In addition, the presence of a second, temporally located area of peak density (which may or may not be foveated) has been reported in many of the groups of birds mentioned above. This indicates that in A. tzacatl and C. anna, as well as in many other avian species, the lateral, monocular visual fields (viewed by the central high-density areas) and the frontal, binocular visual field (viewed by the temporal high-density areas) are of particular importance, irrespectively of their specific ecological niches. Having said this, differences in foveal organization and location, for example, may reflect adaptations to specific niches [Lisney et al., 2013b; Coimbra et al., 2014b]. Future studies should measure visual fields in 
hummingbirds in order to assess the degree to which the central and temporal retinal specializations we identified in A. tzacatl and C. anna map on to the monocular and binocular visuals fields [e.g. Hayes et al., 1987, 1991].

It has been suggested that the central fovea in birds serves to view relatively distant objects in a lateral, monocular field of vision with a high resolution, while the temporal fovea/high-density area is used for detailed, near-object vision in the frontal, binocular field [Walls, 1942; Fite and Rosenfield-Wessels, 1975; Wallman and Pettigrew, 1985; Frost et al., 1990; Collin, 1999]. In A. tzacatl and C. anna, the increased SRP in the frontal, binocular visual field afforded by the temporal area is likely particularly important for mediating precise positioning of the bill during feeding, such as when docking with food flowers [Lee et al., 1991] or catching insects and other arthropods [del Hoyo et al., 1999]. Indeed, a small proportion of the diet of many species of hummingbirds, including A. tzacatl, C. anna, and P. superciliosus, is comprised of insects and spiders, which they catch by aerial hawking or gleaning from foliage, branches, and spider webs [Wagner, 1946; Pearson, 1954; Stiles, 1995; del Hoyo et al., 1999; Warwick et al., 2012]. Interestingly, brown honeyeaters (Lichmera indistincta), which are nectarivorous passerine birds that also occasionally feed on insects, have a retinal topography similar to that of $A$. tzacatl and $C$. anna [Coimbra et al., 2014b].

In A. tzacatl and C. anna, the central and temporal areas of high neuron density are connected by a weak visual streak. Visual streaks serve to increase spatial resolution across the horizon and are generally found in species that live in open habitats dominated by a horizon [Hughes, 1977; Collin, 1999]. A similar retinal topography has been found in eagles, falcons, and vultures [Inzunza et al., 1991; Lisney et al., 2013b], tyrant flycatchers [Coimbra et al., 2006, 2009], and other passerines [Coimbra et al., 2014b]. A. tzacatl and C. anna occupy a range of enclosed (e.g. woodland) and relatively open (e.g. forest clearings and savanna) microhabitats. Presumably the weak visual streak found in these species allows for some degree of panoramic scanning of the lateral visual fields when, for example, perching on the edge of a woodland clearing or flying between flower patches and may be useful for tasks such as predator detection and orientation with respect to the horizon during flight [Collin, 1999].

\section{Neuron Numbers, Densities, and SRP}

On the basis of our results, $A$. tzacatl and C. anna have between half a million and 3 quarters of a million neurons in the RGC layer, peak cell densities in the range of $\sim 45,000$ cells $\cdot \mathrm{mm}^{-2}$, and average cell densities of around 20,000 cells $\cdot \mathrm{mm}^{-2}$. As mentioned previously, these values include the displaced amacrine cell population and so may have to be revised downwards if more precise information specific to the RGC population in these birds becomes available. This also applies to our estimates of SRP. Compared to other birds, these hummingbirds generally have low overall numbers of neurons, but relatively high average neuron densities, on account of their eyes and retinas being very small (table 5). Moreover, peak neuron densities in A. tzacatl and C. anna are also relatively high. However, as SRP is largely dictated by eye size [Pettigrew et al., 1988; Collin and Pettigrew, 1989; Lisney and Collin, 2008; Dolan and Fernández-Juricic, 2010], this does not translate into high SRP on account of hummingbirds having such small eyes (table 5). For example, gamefowl, waterfowl, ostriches, and penguins all have lower peak neuron densities than A. tzacatl and C. anna, but they have much larger eyes and thus greater SRP. The neuron densities and eye size values we present in table 5 for $A$. tzacatl and C. anna are most similar to those reported for some small passerines, such as parids and emberizid finches.

Some birds with small eyes (eye axial lengths between 5.2 and $5.5 \mathrm{~mm}$ ), such as L. indistincta (mentioned previously) and the silvereye Zosterops lateralis, have peak neuron densities over 3 times greater $(138,805$ and 129,728 cells $\cdot \mathrm{mm}^{-2}$, respectively [Coimbra et al., 2014b]) than those we report here for hummingbirds. This suggests that it may be possible to pack more RGC into the foveal area in an eye as small as that of a hummingbird. However, hummingbird visual systems may be limited by an overall requirement in these birds to minimize body size and metabolic costs. Sustained hovering flight is extremely metabolically expensive and is limited by body size [Ellington, 1991; Altshuler and Dudley, 2002; Clark and Dudley, 2010; Warwick et al., 2012]. Hummingbirds have to visit and collect suitable quantities of nectar from hundreds of flowers per day in order to survive [Hurly, 1996; del Hoyo et al., 1999], and additional energetic costs are incurred due to territory defense and mating behavior [del Hoyo et al., 1999]. Eyes, along with their recipient visual brain areas, are energetically costly to build and maintain, and they also require significant quantities of energy to process neural information [Laughlin, 2001a, b; Niven and Laughlin, 2008]. The eyes themselves may incur additional costs, such as mass or drag [Brooke et al., 1999; Laughlin, 2001a]. Therefore, even if the eye size itself did not change in hummingbirds, the addition of more RGC (and concomitant increases in the number of axons in the optic nerve and the size of the retino-recipi- 
Table 5. Retinal topography data, eye axial length, and theoretical peak anatomical SRP in 2 species of hummingbird compared to other birds

\begin{tabular}{|c|c|c|c|c|c|c|c|c|}
\hline & \multirow{2}{*}{$\begin{array}{l}\text { Eye axial } \\
\text { length, } \\
\mathrm{mm}\end{array}$} & \multirow{2}{*}{$\begin{array}{l}\text { Whole- } \\
\text { mount } \\
\text { area }^{\mathrm{a}}, \mathrm{mm}^{2}\end{array}$} & \multicolumn{4}{|c|}{ Neurons in the RGC layer } & \multirow{2}{*}{$\begin{array}{l}\text { SRP, cycles } \\
\text { degree }^{-1}\end{array}$} & \multirow[t]{2}{*}{ References } \\
\hline & & & total, $\mathrm{n} \cdot 10^{6}$ & $\begin{array}{l}\text { average density, } \\
\text { cells } \cdot \mathrm{mm}^{-2}\end{array}$ & region of the retina & $\begin{array}{l}\text { peak density, } \\
\text { cells } \cdot \mathrm{mm}^{-2}\end{array}$ & & \\
\hline $\begin{array}{l}\text { Seabirds } \\
\text { (Procellariiformes) }\end{array}$ & - & $116-734$ & $0.6-3.01$ & $1,587-6,294$ & $\begin{array}{l}\text { Central high-density } \\
\text { area within visual streak }\end{array}$ & $8,900-21,500$ & - & Hayes and Brooke [1990] \\
\hline $\begin{array}{l}\text { Ostrich } \\
\text { (Struthio camelus) }\end{array}$ & 38.9 & 2,588 & 2.27 & 880 & $\begin{array}{l}\text { Central high-density } \\
\text { area within visual streak }\end{array}$ & 9,500 & $17.04-22.55$ & Boire et al. [2001] \\
\hline $\begin{array}{l}\text { Penguins } \\
\text { (Spheniscidae) }\end{array}$ & $17.3-25.7$ & $648-1,283$ & $1.11-1.72$ & $865-2,175$ & $\begin{array}{l}\text { Central high-density } \\
\text { area within visual streak }\end{array}$ & $10,000-21,867$ & $\begin{array}{l}12.81-15.3 \\
(17.07-20.4)^{b}\end{array}$ & $\begin{array}{l}\text { Suburo et al. [1991]; } \\
\text { Coimbra et al. [2012] }\end{array}$ \\
\hline Barn owl (Tyto alba) & $18.5-19$ & $253-336$ & $1.31-1.4$ & $4,167-6,065$ & $\begin{array}{l}\text { Temporal high-density } \\
\text { area }\end{array}$ & $12,500-16,780$ & 8 & $\begin{array}{l}\text { Wathey and Pettigrew } \\
\text { [1989]; Lisney et al. [2012b] }\end{array}$ \\
\hline Waterfowl (Anatidae) & $12-21$ & $154-424$ & $1.35-3.06$ & $7,086-8,986$ & $\begin{array}{l}\text { Central high-density } \\
\text { area within visual streak }\end{array}$ & $17,143-25,306$ & $10.1-16.9$ & Lisney et al. [2013a] \\
\hline \multirow{2}{*}{$\begin{array}{l}\text { Cathartid vultures } \\
\text { (Cathartidae) }\end{array}$} & \multirow[t]{2}{*}{$18.2-18.9$} & \multirow[t]{2}{*}{$540-594$} & \multirow[t]{2}{*}{$3.8-3.9$} & \multirow[t]{2}{*}{$6,637-7,086$} & Central fovea & $21,225-23,796$ & $15.4-15.8^{\mathrm{c}}$ & \multirow[t]{2}{*}{ Lisney et al. [2013b] } \\
\hline & & & & & $\begin{array}{l}\text { Temporal high-density } \\
\text { area }\end{array}$ & $15,891-17,361$ & $13.4-13.5$ & \\
\hline Gamefowl (Phasianidae) & $9.3-19.4$ & $98-424$ & $1.51-3.31$ & $8,703-8,986$ & $\begin{array}{l}\text { Central high-density } \\
\text { area }\end{array}$ & $22,050-35,609$ & $9.7-20.6$ & $\begin{array}{l}\text { Hart [2002]; Lisney et al. } \\
\text { [2012a] }\end{array}$ \\
\hline Strigid owls (Strigidae) & $16.8-36.5$ & $200-927$ & $1.95-6.92$ & $7,410-13,855$ & Temporal fovea & $22,355-34,157$ & - & $\begin{array}{l}\text { Bravo and Pettigrew [1981]; } \\
\text { Lisney et al. [2012b] }\end{array}$ \\
\hline $\begin{array}{l}\text { Emberizid passerines } \\
\text { (Emberizidae) }\end{array}$ & $5.4-7.6$ & $62-153$ & $1.36-2.73$ & $17,882-23,423$ & Centro-temporal fovea & $24,000-47,920$ & $6.45-8.35^{c}$ & Moore et al. [2015] \\
\hline Parid passerines (Paridae) & $5.2-6.6$ & - & - & $15,189-15,467$ & Central fovea & $28,969-31,339$ & $4.97-6.57^{c}$ & Moore et al. [2013] \\
\hline \multirow{2}{*}{ Pigeon (Columba livia) } & \multirow[t]{2}{*}{11.7} & \multirow[t]{2}{*}{332} & \multirow[t]{2}{*}{2.38} & \multirow[t]{2}{*}{7.169} & Central fovea & 41,000 & - & \multirow{2}{*}{$\begin{array}{l}\text { Hayes and Holden [1983]; } \\
\text { Lisney et al. [unpubl. data] }\end{array}$} \\
\hline & & & & & $\begin{array}{l}\text { Dorso-temporal high } \\
\text { density area }\end{array}$ & 36,000 & 13.9 & \\
\hline \multirow[t]{2}{*}{ Cockatoos (Cacatuidae) } & \multirow[t]{2}{*}{$8.6-14.6$} & \multirow[t]{2}{*}{$162-482$} & \multirow[t]{2}{*}{$0.93-2.12$} & \multirow[t]{2}{*}{$4,214-6,146$} & Central fovea & $43,750-59,000$ & - & \multirow[t]{2}{*}{ Coimbra et al. [2014b] } \\
\hline & & & & & $\begin{array}{l}\text { Dorso-temporal high- } \\
\text { density area }\end{array}$ & $6,800-16,533$ & $7.4-9.8$ & \\
\hline \multirow{2}{*}{$\begin{array}{l}\text { Rufous-tailed } \\
\text { hummingbird } \\
\text { (A. tzacatl) }\end{array}$} & \multirow[t]{2}{*}{4.4} & \multirow[t]{2}{*}{36} & \multirow[t]{2}{*}{0.7} & \multirow[t]{2}{*}{19,462} & $\begin{array}{l}\text { Central high-density } \\
\text { area }\end{array}$ & 44,898 & 5.8 & \multirow[t]{2}{*}{ This study } \\
\hline & & & & & $\begin{array}{l}\text { Temporal high-density } \\
\text { area }\end{array}$ & 38,367 & 5.4 & \\
\hline Anna's hummingbird & 4.3 & 26 & 0.57 & 22,304 & Central fovea & 47,619 & - & This study \\
\hline (C. anna) & & & & & $\begin{array}{l}\text { Temporal high-density } \\
\text { area }\end{array}$ & 38,912 & 5.3 & \\
\hline Tyrant flycatchers & - & $74-240$ & $1.92-4.15$ & $11,709-40,249$ & Central fovea & $55,000->150,000$ & - & Coimbra et al. $[2006,2009]$ \\
\hline (Tyrannidae) & & & & & $\begin{array}{l}\text { Temporal high-density } \\
\text { area }\end{array}$ & $40,000-\sim 80,000$ & - & \\
\hline $\begin{array}{l}\text { Chilean tinamou } \\
\text { (Nothoprota perdicaria) }\end{array}$ & 10.7 & 257 & 4.3 & 16,800 & Central fovea & 61,900 & $14^{\mathrm{c}}$ & Krabichler et al. [2015] \\
\hline Black-chested & - & 690 & - & - & Central fovea & 62,000 & - & Inzunza et al. [1991] \\
\hline $\begin{array}{l}\text { buzzard-eagle } \\
\text { (Geranoaetus melanoleucus) }\end{array}$ & & & & & Temporal fovea & 45,000 & - & \\
\hline American kestrel & - & 275 & - & - & Central fovea & 65,000 & - & Inzunza et al. [1991] \\
\hline (Falco sparverius) & & & & & Temporal fovea & 45,000 & - & \\
\hline $\begin{array}{l}\text { Meliphagoid passerines } \\
\text { (Meliphaoidea) }\end{array}$ & $5.2-11.1$ & $67-291$ & $1.47-4.7$ & $16,162-30,899$ & Central fovea & $\begin{array}{l}129,728- \\
157,397 \\
\end{array}$ & - & Coimbra et al. [2014a] \\
\hline & & & & & $\begin{array}{l}\text { Temporal high-density } \\
\text { area }\end{array}$ & $41,716-54,400$ & $7.2-14.2$ & \\
\hline Kingfishers (Alcedines) & - & - & - & - & Central fovea & $\begin{array}{l}160,000- \\
180,000\end{array}$ & $26-41^{c}$ & $\begin{array}{l}\text { Moroney and Pettigrew } \\
\text { [1987] }\end{array}$ \\
\hline & & & & & Temporal fovea & $25,000-40,000$ & - & \\
\hline
\end{tabular}

a Refers to the area of the whole mount after staining. ${ }^{b}$ Values refer to SRP in air and underwater (values in parentheses). ${ }^{\mathrm{c}}$ The use of peak RGC densities around the fovea to calculate SRP is problematic and these values should be interpreted with caution (see Materials and Methods and Coimbra et al. [2014a, b; 2015]). ${ }^{\mathrm{d}}$ Eye axial length and SRP.

ent brain areas, and perhaps other neural structures involved with visual processing) could result in increases in both overall body mass and metabolic expenditure that are too great for birds already living at physiological and biomechanical extremes [Altshuler and Dudley, 2002].

\section{Comparisons with Wood [1917]}

To our knowledge, the only other description of a hummingbird retina is that presented by Casey Wood [1917], who described the fundus and pecten macroscopically in C. anna. Our retinal topography map and retinal 
reconstruction for this same species are very similar to the original illustration of Wood [1917] (fig. 4), but we could not confirm the presence of a second fovea located in the temporal retina. A temporal fovea located so close to the retinal margin as reported by Wood [1917] would be unusual in birds, with only kingfishers apparently having fovea located in a somewhat similar location [Wood, 1917; Moroney and Pettigrew, 1987]. In contrast, a second area of high cell density (which may or may not be foveated) located approximately midway between the central fovea and the temporal margin of the retina (as we found in A. tzacatl and C. anna) is quite common and has been reported in falcons, eagles, vultures [Slonaker, 1897; Wood, 1917; Fite and Rosenfield-Wessels, 1975; Inzunza et al., 1991], terns [Slonaker, 1897; Fite and RosenfieldWessels, 1975], and a variety of passerines [Coimbra et al., 2006, 2009, 2014b, 2015]. The reasons for the discrepancy between our work and that of Wood [1917] are unclear. As mentioned previously, it can be difficult to identify foveas in whole-mounted retinas. However, we feel that it is unlikely that we missed the presence of a temporal fovea in our sectioned material for two reasons: (1) we experienced no issues with folding for either of the retinas that we sectioned, and (2) we analyzed every single section from the region of the retina where Wood [1917] stated the fovea to be. Therefore, we suggest that $C$. anna and potentially other hummingbirds are not bifoveate, although it will be important to confirm this is in a broader range of species.

\section{Acknowledgements}

The authors thank Kenneth Welch Jr. (University of Toronto) and Lainy Day (University of Mississippi) for providing us with the hummingbird eyes used in this study. Janet Menard (Queen's University) kindly provided access to the microscope and digital camera system used in the reconstruction of cross-sectioned retinas. The comments from two anonymous reviewers greatly improved this paper. Funding was provided by Natural Sciences and Engineering Council of Canada (NSERC) grants to Andrew N. Iwaniuk and Douglas R. Wylie.

\section{References}

Ahnelt PK, Schubert C, Kübber-Heiss A, Schiviz Chen DM, Collins JS, Goldsmith TH (1984): The A, Anger E (2006): Independent variation of retinal S and $\mathrm{M}$ cone photoreceptor topographies: a survey of four families of mammals. Vis Neurosci 23:429-435.

-Altshuler DL (2003): Flower color, hummingbird pollination, and habitat irradiance in four neotropical forests. Biotropica 35:344-355.

Altshuler DL, Dudley R (2002): The ecological and evolutionary interface of hummingbird flight physiology. J Exp Biol 205:2325-2336.

Bailes HJ, Trezise AEO, Collin SP (2006): The number, morphology, and distribution of retinal ganglion cells and optic axons in the Australian lungfish Neoceratodus forsteri (Krefft 1870). Vis Neurosci 23:257-273.

-Binggeli RL, Paule WJ (1969): The pigeon retina: quantitative aspects of the optic nerve and ganglion cell layer. J Comp Neurol 137:1-18.

- Boire D, Dufour JS, Theoret H, Ptito M (2001): Quantitative analysis of the retinal ganglion cell layer in the ostrich, Struthio camelus. Brain Behav Evol 58:343-355.

Bravo H, Pettigrew JD (1981): The distribution of neurons projecting from the retina and visual cortex to the thalamus and tectum opticum of the barn owl, Tyto alba, and the burrowing owl, Speotyto cunicularia. J Comp Neurol 199: 419-441.

Brooke MD, Hanley S, Laughlin SB (1999): The scaling of eye size with body mass in birds. Proc R Soc Lond B 266:405-412. ultraviolet receptor of bird retinas. Science 225:337-340.

-Chen Y, Naito J (1999): A quantitative analysis of the cells in the ganglion cell layer of the chick retina. Brain Behav Evol 53:75-86.

Clark CJ, Dudley R (2010): Hovering and forward flight energetics in Anna's and Allen's hummingbirds. Phys Biochem Zool 83:654-662.

Coimbra JP, Collin SP, Hart NS (2014a): Topographic specializations in the retinal ganglion cell layer correlate with lateralized visual behaviour, ecology, and evolution in cockatoos. J Comp Neurol 522:3363-3385.

Coimbra JP, Collin SP, Hart NS (2014b): Topographic specializations in the retinal ganglion cell layer of Australian passerines. J Comp Neurol 522:3609-3628.

Coimbra JP, Collin SP, Hart NS (2015): Variations in retinal photoreceptor topography and the organization of the rod-free zone reflect behavioural diversity in Australian passerines. J Comp Neurol 523:1073-1094.

Coimbra JP, Marceliano MLV, Andrade-da-Costa BLS, Yamada ES (2006): The retina of tyrant flycatchers: topographic organization of neuronal density and size in the ganglion cell layer of the great kiskadee Pitangus sulphuratus and the rusty margined flycatcher Myiozetetes cayanensis (Aves: Tyrannidae). Brain Behav Evol 68:15-25.
Coimbra JP, Nolan PM, Collin SP, Hart NS (2012): Retinal ganglion cell topography and spatial resolving power in penguins. Brain Behav Evol 80:254-268.

-Coimbra JP, Trévia N, Marceliano ML, da Silveira Andrade-Da-Costa BL, Picanço-Diniz CW, Yamada ES (2009): Number and distribution of neurons in the retinal ganglion cell layer in relation to foraging behaviors of tyrant flycatchers. J Comp Neurol 514:66-73.

Collin SP (1988): The retina of the shovel-nosed ray, Rhinobatos batillum (Rhinobatidae): morphology and quantitative analysis of the ganglion, amacrine and bipolar cell populations. Exp Biol 47:195-207.

Collin SP (1999): Behavioural ecology and retinal cell topography; in Archer SN, Djamgoz MBS, Loew ER, Partridge JC, Vellarga S (eds): Adaptive Mechanisms in the Ecology of Vision. Dordrecht, Kluwer, pp 509-535.

Collin SP (2008): A web-based archive for topographic maps of retinal cell distribution in vertebrates. Clin Exp Optom 91:85-95.

Collin SP, Pettigrew JD (1988): Retinal ganglion cell topography in teleosts: a comparison between Nissl-stained material and retrograde labelling from the optic nerve. J Comp Neurol 276:412-422.

Collin SP, Pettigrew JD (1989): Quantitative comparison of the limits on visual spatial resolution set by the ganglion cell layer in twelve species of reef teleosts. Brain Behav Evol 34: 184-192. 
Curcio CA, Allen KA (1990): Topography of ganglion cells in the human retina. J Comp Neurol 300:5-25.

- del Hoyo J, Elliott A, Sargatal J (eds) (1999): Handbook of the Birds of the World: BarnOwls to Hummingbirds. Barcelona, Lynx, vol 5.

Dolan T, Fernández-Juricic E (2010): Retinal ganglion cell topography of five species of ground-foraging birds. Brain Behav Evol 75: 111-121.

-Drasdo N, Millican CL, Katholi CR, Curcio CA (2007): The length of Henle fibers in the human retina and a model of ganglion cell receptive field density in the visual field. Vision Res 47:2901-2911.

Ehrlich D (1981): Regional specialization of the chick retina as revealed by the size and density of neurons in the ganglion cell layer. J Comp Neurol 195:643-657.

Ellington CP (1991): Limitations on animal flight performance. J Exp Biol 160:71-91.

-Fernández-Juricic E, Moore BA, Doppler M, Freeman J, Blackwell BF, Lima SL, DeVault TL (2011a): Testing the terrain hypothesis: Canada geese see their world laterally and obliquely. Brain Behav Evol 77:147-158.

-Fernández-Juricic E, Gall MD, Dolan T, O’Rourke C, Thomas S, Lynch JR (2011b): Visual systems and vigilance behaviour of two groundforaging avian prey species: white-crowned sparrows and California towhees. Anim Behav 81:705-713.

Fite KV, Rosenfield-Wessels S (1975): A comparative study of deep avian foveas. Brain Behav Evol 12:97-115.

Frost BJ, Wise LZ, Morgan B, Bird D (1990): Retinotopic representation of the bifoveate eye of the kestrel (Falco sparverius) on the optic tectum. Vis Neurosci 5:231-239.

George MW (1980): Hummingbird foraging behavior at Malvaviscus arboreus var. drummondii. Auk 97:790-794.

-Gioanni H, Rey J, Villalobos J, Richard D, Dalbera A (1983): Optokinetic nystagmus in the pigeon (Columba livia). 2. Role of the pretectal nucleus of the accessory optic system. Exp Brain Res 50:237-247.

Goldsmith TH (1980): Hummingbirds see near ultraviolet light. Science 207:786-788.

-Goldsmith TH, Collins JS, Licht S (1984): The cone oil droplets of avian retinas. Vision Res 11:1661-1671.

Goldsmith TH, Collins JS, Perlman DL (1981): A wavelength discrimination function for the hummingbird Archilochus alexandri. J Comp Physiol 143:103-110.

Goldsmith TH, Goldsmith KM (1979): Discrimination of colors by the black-chinned hummingbird, Archilochus alexandri. J Comp Physiol 130:209-220.

-Goller B, Altshuler DL (2014): Hummingbirds control hovering flight by stabilizing visual motion. Proc Natl Acad Sci USA 111:1837518380.
Grant KA (1966): A hypothesis concerning the prevalence of red coloration in California hummingbird flowers. Am Nat 100:85-97.

Greenewalt CH (1960): Hummingbirds. New York, Doubleday.

Greenewalt CH, Brandt W, Friel DD (1960): The iridescent colors of hummingbird feathers. Proc Am Phil Soc 104:249-253.

Gundersen HJG (1977): Notes on the estimation of the numerical density of arbitrary particles: the edge effect. J Microsc 111:219-223.

Hall MI (2008): Comparative analysis of the size and shape of the lizard eye. Zoology 111:6275.

Hall MI, Ross CF (2007): Eye shape and activity pattern in birds. J Zool 271:437-444.

Hart NS (2002): Vision in the peafowl (Aves: Pavo cristatus). J Exp Biol 205:3925-3935.

Hayes BP (1984): Cell populations of the ganglion cell layer: displaced amacrine and matching amacrine cells in the pigeon retina. Exp Brain Res 56:565-573.

Hayes BP, Brooke MD (1990): Retinal ganglion cell distribution and behaviour in procellariiform seabirds. Vision Res 30:1277-1289.

-Hayes BP, Hodos W, Holden AL, Low JC (1987): The projection of the visual field upon the retina of the pigeon. Vision Res 27:31-40.

Hayes BP, Holden AL (1983): The distribution of displaced ganglion cells in the retina of the pigeon. Exp Brain Res 49:181-188.

Hayes BP, Martin GR, Brooke MD (1991): Novel area serving binocular vision in the retinae of procellariiform seabirds. Brain Behav Evol 37: 79-84.

-Healy S, Hurly TA (2006): Hummingbirds. Curr Biol 16:R392-R393.

-Herrera G, Zagal JC, Diaz M, Fernández MJ, Vielma A, Cure M, Martinez J, Bozinovic F, Palacios AG (2008): Spectral sensitivities of photoreceptors and their role in colour discrimination in the green-backed firecrown hummingbird (Sephanoides sephaniodes). J Comp Physiol A Neuroethol Sens Neural Behav Physiol 194:785-794.

Howland HC, Merola S, Basarab JR (2004): The allometry and scaling of the size of vertebrate eyes. Vision Res 44:2043-2065.

Hughes A (1977): The topography of vision in mammals of contrasting lifestyles: comparative optics and retinal organization; in Cresitelli F (ed): Handbook of Sensory Physiology. Berlin, Springer, pp 613-756, vol VIII/5.

Hughes A (1985): New perspectives in retinal organization; in Osbourne NN, Chader G (eds): Progress in Retinal Research. New York, Pergamon Press, pp 243-313.

Hurly TA (1996): Spatial memory in rufous hummingbirds: memory for rewarded and nonrewarded sites. Anim Behav 51:177-183.

Inzunza O, Bravo H, Smith RL, Angel M (1991): Topography and morphology of retinal ganglion cells in Falconiformes: a study on predatory and carrion-eating birds. Anat Rec 229: 271-277.
Iwaniuk AN, Wylie DRW (2007): Neural specialization for hovering in hummingbirds: hypertrophy of the pretectal nucleus lentiformis mesencephali. J Comp Neurol 500:211-221.

Kirk EC (2004): Comparative morphology of the eye in primates. Anat Rec 281A:1095-1103.

Kirk EC (2006): Eye morphology in cathemeral lemurids and other mammals. Folia Primatol 77:27-49.

Krabichler Q, Vega-Zuniga T, Morales C, Luksch H, Marin GJ (2015): The visual system of a Palaeognathous bird: visual field, retinal topography and retino-central connections in the Chilean tinamou (Nothoprocta perdicaria). J Comp Neurol 523:226-250.

Land MF, Nilsson DE (2002): Animal Eyes. Oxford, Oxford University Press.

Laughlin SB (2001a): The metabolic cost of information - a fundamental factor in visual ecology; in Barth FG, Schmid A (eds): Ecology of Sensing. Berlin, Springer, pp 169-186.

Laughlin SB (2001b): Energy as a constraint on the coding and processing of sensory information. Curr Opin Neurobiol 11:475-480.

-Lee DN, Reddish PE, Rand DT (1991): Aerial docking by hummingbirds. Naturwissenschaften 78:526-527.

Lisney TJ, Collin SP (2008): Retinal ganglion cell distribution and spatial resoling power in elasmobranchs. Brain Behav Evol 72:59-77.

- Lisney TJ, Iwaniuk AN, Kolominsky J, Bandet MV, Corfield JR, Wylie DW (2012a): Interspecifc variation in eye shape and retinal topography in seven species of galliform bird (Aves: Galliformes: Phasianidae). J Comp Physiol A Neuroethol Sens Neural Behav Physiol 198:717-731.

- Lisney TJ, Iwaniuk AN, Bandet MV, Wylie DW (2012b): Eye shape and retinal topography in owls (Aves: Strigiformes). Brain Behav Evol 79:218-236.

Lisney TJ, Stecyk K, Kolominsky J, Schmidt BK, Corfield JR, Iwaniuk AN, Wylie DW (2013a): Ecomorphology of eye shape and retinal topography in waterfowl (Aves: Anseriformes: Anatidae) with different foraging modes. J Comp Physiol A Neuroethol Sens Neural Behav Physiol 199:385-402.

Lisney TJ, Stecyk K, Kolominsky J, Schmidt BK, Corfield JR, Iwaniuk AN, Wylie DW (2013b): Comparison of eye morphology and retinal topography in two species of new world vultures (Aves: Cathartidae). Anat Rec 296: 1954-1970.

- Martin GR, Wilson KJ, Wild JM, Parsons S, Kubke MF, Corfield J (2007): Kiwis forego vision in the guidance of their nocturnal activities. PLoS One 2:e198.

McGuire JA, Witt CC, Altshuler DL, Remsen JV Jr (2007): Phylogenetic systematics and biogeography of hummingbirds: Bayesian and maximum likelihood analyses of partitioned data and selection of an appropriate partitioning strategy. Syst Biol 56:837-856. 
-McGuire JA, Witt CC, Remsen JV Jr, Corl A, Q Querubin A, Lee HR, Provis JM, O’Brien KM Rabosky DL, Altshuler DL, Dudley R (2014): Molecular phylogenetics and the diversification of hummingbirds. Curr Biol 24:910-916.

McKenna O, Wallman J (1985): Accessory optic system and pretectum of birds: comparisons with those of other vertebrates. Brain Behav Evol 26:91-116.

-Meadows MG, Roudybush TE, McGraw KJ (2012): Dietary protein affects iridescent coloration in Anna's hummingbirds, Calypte anna. J Exp Biol 215:2742-2750.

Miller RS, Miller RE (1971): Feeding activity and color preference of ruby-throated hummingbirds. Condor 73:309-313.

Moore BA, Doppler M, Young JE, Fernández-Juricic $\mathrm{E}$ (2013): Interspecific differences in the visual system and scanning behavior of three forest passerines that form heterospecific flocks. J Comp Physiol A Neuroethol Sens Neural Behav Physiol 199:263-277.

Moore BA, Pita D, Tyrrell LP, Fernández-Juricic E (2015): Vision in avian emberizid foragers: maximizing both binocular vision and fronto-lateral visual acuity. J Exp Biol 218:13471358.

Moroney MK, Pettigrew JD (1987): Some observations on the visual optics of kingfishers (Aves, Coraciformes, Alcedinidae). J Comp Physiol A Neuroethol Sens Neural Behav Physiol 160:137-149.

Diven JE, Laughlin SB (2008): Energy limitation as a selective pressure on the evolution of sensory systems. J Exp Biol 211:1792-1804.

-Ödeen A, Håstad O (2010): Pollinating birds differ in spectral sensitivity. J Comp Physiol A Neuroethol Sens Neural Behav Physiol 196: 91-96.

Parra JL (2010): Color evolution in the hummingbird genus Coeligena. Evolution 64:324-335.

$\checkmark$ Pearson OP (1954): The daily energy requirements of a wild Anna hummingbird. Condor 56:317-322.

Peterson EH, Ulinski PS (1979): Quantitative studies of retinal ganglion cells in a turtle, Pseudemys scripta elegans. 1. Number and distribution of ganglion cells. J Comp Neurol 186:17-42.

Pettigrew JD, Bhagwandin A, Haagensen M, Manger PR (2010): Visual acuity and heterogeneities of retinal ganglion cell densities and the tapetum lucidum of the African elephant (Loxodonta africana). Brain Behav Evol 75: 251-261.

- Pettigrew JD, Dreher B, Hopkins CS, McCall MJ, Brown M (1988): Peak density and distribution of ganglion cells in the retinae of microchiropteran bats: implications for visual acuity. Brain Behav Evol 32:39-56.

Pettigrew JD, Manger PR (2008): Retinal ganglion cell density of the black rhinoceros (Diceros bicornis): calculating visual resolution. Vis Neurosci 25:215-220.

- Provis JM, Dubis AM, Maddess T, Carroll J (2013): Adaptation of the central retina for high acuity vision: cones, the fovea and the avascular zone. Prog Retin Eye Res 35:63-81. (2009): Photoreceptor and ganglion cell tovergence and high acute regions in the adult pigeon (Columba livia) retina. J Comp Neurol 517:711-722.

Rasband WS (1997-2015): ImageJ. Bethesda, US National Institutes of Health. http://imagej. nih.gov/ij/.

Reymond L (1985): Spatial visual acuity of the eagle Aquila audax: a behavioural, optical and anatomical investigation. Vision Res 25: 1477-1491.

Reymond L (1987): Spatial visual acuity of the falcon, Falco berigora: a behavioural, optical and anatomical investigation. Vision Res 27: 1859-1874.

Ritland S (1982): The Allometry of the Vertebrate Eye; PhD thesis, University of Chicago, Chicago.

Schaeffer RL, Mendenhall W, Ott L (1996): Elementary Survey Sampling, ed 5. Boston, PWS-Kent.

Schiviz AN, Ruf T, Kuebber-Heiss A, Schubert C, Ahnelt PK (2008): Retinal cone topography of artiodactyl mammals: influence of body height and habitat. J Comp Neurol 507:13361350 .

Schmitz C, Hof PR (2000): Recommendations for straightforward and rigorous methods of counting neurons based on a computer simulation approach. J Chem Neuroant 20:93114.

-Slomianka L, West MJ (2005): Estimators of the precision of stereological estimates: an example based on the CA1 pyramidal cell layer of rats. Neurosci 136:757-767.

Slonaker JR (1897): A comparative study of the area of acute vision in vertebrates. J Morphol 13:445-502.

Snyder AW, Miller WH (1977): Photoreceptor diameter and spacing for highest spatial resolving power. J Opt Soc Am 67:696-698.

Stiles FG (1982): Aggressive and courtship displays of the male Anna's hummingbird. Condor 84:208-255.

Stiles FG (1995): Ecological and morphological correlates of foraging for arthropods by the hummingbirds of a tropical wet forest. Condor 97:853-878.

Stone J (1981): The Wholemount Handbook: a Guide to the Preparation and Analysis of Retinal Wholemounts. Sydney, Clarendon Press.

$\checkmark$ Stone J, Johnston E (1981): The topography of primate retina: a study of the human, bushbaby, and New- and Old-World monkeys. J Comp Neurol 196:205-223.

Suburo AM, Herrero MV, Scolaro JA (1991): Regionalization of the ganglion cell layer in the retina of the Magellanic penguin (Spheniscus magellanicus). Colon Waterbird 14:17-24. pographies correlate with information con-
Ullmann JFP, Moore BA, Temple SH, FernándezJuricic E, Collin SP (2012): The retinal wholemount technique: a window to understanding the brain and behaviour. Brain Behav Evol 79:26-44.

Veilleux CC, Lewis RJ (2011): Effects of habitat light intensity on mammalian eye shape. Anat Rec 294:905-914.

Waespe W, Henn V (1987): Gaze stabilization in the primate: the interaction of the vestibuleocular reflex, optokinetic nystagmus, and smooth pursuit. Rev Physiol Biochem Pharmacol 106:37-125.

Wagner, HO (1946): Food and feeding habits of Mexican hummingbirds. Condor 58:69-93.

Wallman J, Pettigrew JD (1985): Conjugate and disjunctive saccades in two avian species with contrasting oculomotor strategies. J Neurosci 5:1418-1428

Walls GL (1942): The Vertebrate Eye and Its Adaptive Radiation. Bloomfield Hills, Cranbrook Institute of Science.

-Ward BJ, Day LB, Wilkening SR, Wylie DR, Saucier DM, Iwaniuk AN (2012): Hummingbirds have a greatly enlarger hippocampal formation. Biol Lett 8:657-659.

Warwick D, Hedrick T, Fernandez MJ, Tobalske B, Biewener A (2012): Hummingbird flight. Curr Biol 22:R472-R477.

Wässle H (2004): Parallel processing in the mammalian retina. Nat Rev Neurosci 5:747-757.

Wässle H, Boycott BB (1991): Functional architecture of the mammalian retina. Physiol Rev 71:447-480.

Wässle H, Grünert U, Röhrenbeck J, Boycott BB (1990): Retinal ganglion cell density and cortical magnification factor in the primate. Vision Res 30:1897-1911.

Wathey JC, Pettigrew JD (1989): Quantitative analysis of the retinal ganglion cell layer and optic nerve of the barn owl Tyto alba. Brain Behav Evol 33:279-292.

West MJ (2012): Basic Stereology for Biologists and Neuroscientists. Cold Spring Harbor, Cold Spring Harbor Laboratory Press.

West MJ, Slomianka L, Gundersen HJG (1991): Unbiased stereological estimation of the total number of neurons in the subdivisions of the rat hippocampus using the optical fractionator. Anat Rec 231:482-497.

Williams DR, Coletta NJ (1987): Cone spacing and the visual resolution limit. J Opt Soc Am A 4:1514-1523.

Winterson BJ, Brauth SE (1985): Direction-selective single units in the nucleus lentiformis mesencephali of the pigeon (Columba livia). Exp Brain Res 60:215-226.

Wood CA (1917): The Fundus Oculi of Birds, Especially as Viewed by the Ophthalmoscope: a Study in Comparative Anatomy and Physiology. Chicago, Lakeside Press.

Wylie DR, Crowder NA (2000): Spatiotemporal properties of fast and slow neurons in the pretectal nucleus lentiformis mesencephali in pigeons. J Neurophysiol 84:2529-2540. 